\title{
Editorial
}

\section{La desindustrialización en Colombia}

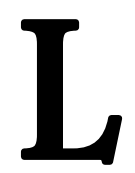

a participación de la industria colombiana en el PIB tuvo su máximo valor en 1975, cuando alcanzó 23,2\%; posteriormente, en el decenio de los 80 disminuyó a $21,3 \%$, en promedio, pero, a partir de los noventa, se redujo notoriamente, hasta situarse en $15,1 \%$. Hoy representa el 11,2\%, es decir, 12 puntos porcentuales por debajo del año de mayor participación.

La reducción en la contribución de la industria al PIB es normal, tanto para países desarrollados como en vías de desarrollo; en los primeros, cuando la misma alcanza niveles del $30 \%$ del PIB, comienza a bajar su peso, y se inicia un crecimiento del sector de servicios, debido a los avances tecnológicos incorporados en este último.

En el caso colombiano, la desindustrialización coincide con el proceso aperturista de los noventa y se agudiza con la adopción de los TLC firmados en el país y por la revaluación del peso.

La apertura económica se inició en marzo de 1990 y, una vez posesionado el presidente Gaviria, se consolidó. La apertura económica no solo se asocia a la liberalización del sector externo, sino a una serie de reformas como la cambiaria, la laboral, la tributaria, entre otras, todas inspiradas en el Consenso de Washington, para, supuestamente, mediante los ajustes macroeconómicos, lograr el crecimiento económico. De hecho, con las reformas se esperaba que el mercado asignara los recursos. En otras palabras, la libre actuación de la oferta y la demanda enviaría señales de eficiencia. De igual manera era necesario eliminar todo aquello que interfiriera en la libre formación del precio de un bien o servicio. De ahí la exigencia de desmontar todo el sistema de incentivos, subsidios, aranceles, etc. Además, comienza a cuestionarse el papel del Estado, que no debe interferir en la actividad económica sino fomentar la seguridad social y ofrecer la infraestructura básica que ayude a elevar la rentabilidad privada.

En el plan de desarrollo La revolución pacífica (1990 1994), de la administración de César Gaviria quien trasplantó el decálogo del Consenso de Washington a la economía colombiana, tanto en el prólogo, como en la introducción y en el capítulo I se hace toda una exposición de motivos para enfatizar que el Estado, básicamente, debe garantizar la actividad productiva del sector privado, prestar servicios básicos y dejar a las fuerzas del mercado que asignen los recursos. Esto se puede corroborar con las reformas planteadas, todas dirigidas a flexibilizar y a agilizar el funcionamiento de los mercados, y, de esta forma, contribuir a incrementar la eficiencia en la asignación de los recursos. 
En relación con los TLC, se ha vendido la idea de que ofrecen inmejorables condiciones para crecer. Esto es correcto, si se dispone de una buena capacidad productiva, la cual no se construye, solamente, con orientación exportadora. Se necesita una política decidida para crear esta capacidad competitiva, y, además, ofrecer otras condiciones que son determinantes, tales como: una tecnología adecuada y una infraestructura, que contribuyan a elevar la productividad. Se requiere, por lo tanto, lo que algunos llaman, «agenda transversal» que incluya políticas encaminadas a la modernización del aparato productivo, mejorar la calidad y aumentar la cobertura en educación, la modernización del aparato productivo, la ampliación y mantenimiento de la infraestructura física, en especial, las vías, el impulso a sectores competitivos, el mejoramiento de los canales de comercialización, el incremento del presupuesto para ciencia y tecnología, entre otras iniciativas. En algunos de estos frentes, el Gobierno nacional ha realizado ingentes esfuerzos, pero todavía falta mucho por hacer, hasta el punto que ha decidido suspender la suscripción de nuevos tratados y, más bien, concentrar su atención en la política industrial. De todas formas, algunos TLC, sobre todo con los de Estados Unidos, Europa y Corea, tienen deficiencias estructurales, lo que ha llevado a que algunos críticos planteen la necesidad de revisarlos.

Otro elemento que contribuye a la desindustrialización es la revaluación del peso, la cual en los últimos años ha sido considerable, sobre todo a partir del 2003. La apreciación del peso estimula las importaciones y desestimula las exportaciones. Ha sido tan fuerte la revaluación que entidades como la Asociación Nacional de Instituciones Financieras (ANIF) sostiene que en la desindustrialización colombiana el elemento determinante es el comportamiento de la tasa de cambio. Según esta agremiación, en economías como la colombiana donde la mayoría de las exportaciones son commodities, tipo enclave $\sim$, la participación del sector industrial en la economía tiende a reducirse significativamente, es decir, se presenta lo que se conoce como enfermedad holandesa. La abundancia de divisas por concepto de exportaciones de commodities genera una apreciación cambiaria real y persistente, que reduce la competitividad de los demás bienes y servicios producidos en el país, ocasiona una reducción de las exportaciones industriales y agrícolas, y, por consiguiente, estimula considerablemente las importaciones, lo que conduce al desplazamiento de la producción doméstica por la producción extranjera.

De lo anterior se infiere que la apertura comercial, los TLC y la revaluación del peso son elementos decisivos en la desindustrialización del país. Los tres procesos, inspirados en el principio de libertad en el comercio internacional que supone que todos los participantes están en igualdad de competir en los mercados , no es, como lo plantea Stiglitz, libre comercio autentico, sino un régimen de comercio dirigido, en el que priman los intereses empresariales; en otras palabras, es un proceso de negociación que no es ni democrático ni transparente.

Luis Eudoro Vallejo Zamudio

Director de la Revista Apuntes del Cenes 


\section{Editorial}

\section{Deindustrialization in Colombia}

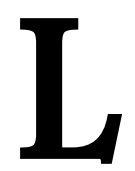

The participation of the Colombian industry in GDP was highest in 1975, when it reached $23.2 \%$; later, in the eighties dropped to $21.3 \%$ on average, but from the nineties, was down sharply to stand at $15.1 \%$. Today it represents $11.2 \%$, i.e., 12 percentage points below the year of the highest participation.

The reduction in the contribution of industry to GDP is normal for both developed and developing countries; in the first, when it reaches levels of $30 \%$ of GDP, its weight starts to drop, and begins the growth in the service sector, due to technological advances incorporated in the latter.

Deindustrialization process in Colombia coincides with the openness of the nineties and intensifies by the adoption of FTAs signed in the country and the appreciation of the Colombian currency (peso).

Economic openness began in March 1990 and once taken possession President Gaviria, it was consolidated. Economic openness is not only associated with the liberalization of the external sector, but a series of reforms such as exchange rate, labor, tax, among others, all inspired by the Washington Consensus, for allegedly, using macroeconomic adjustments achieve economic growth. In fact, with reforms it was expected market to allocate the resources. In other words, that the free play of supply and demand would send signals of efficiency. Similarly it was necessary to eliminate anything that interferes with the free formation of the price of a good or service. Hence the need to dismantle the entire system of incentives, subsidies, tariffs, etc. In addition, it begins to question the role of the State, which should not interfere in economic activity, but to promote social security and provide the basic infrastructure that will help to increase private returns.

The Development Plan “The Peaceful Revolution” (1990 1994), of Cesar Gaviria administration, who transplanted the Washington Consensus Decalogue to the Colombian economy, both in the prologue as in the introduction and Chapter I is all an explanatory statement to emphasize that the State should basically guarantee the productive activity of private sector, provide basic services, and allow market forces to allocate resources. This can be corroborated with the proposed reforms, all aimed to ease and accelerate the functioning of markets, and thus, contribute to increased efficiency in the allocation of resources. 
Regarding FTAs, it has been sold the idea that they offer ideal conditions for growth. This is correct, if the Colombian State has a good production capacity, which is not built only export oriented. A determined policy to create this competitive capacity is needed and also offers other conditions which are determinate, such as an appropriate technology and infrastructure contributing to increase productivity. It requires, therefore, what some call, «transverse agenda» that includes policies aimed at the modernization of the production system, improve quality and increase coverage in education, modernization of production systems, expansion and maintenance of physical infrastructure, especially roads, boosting competitive sectors, improving marketing channels, increasing the budget for science and technology, among other initiatives. In some of these fronts, the national Government has made enormous efforts, but there is still much to do, to the point that it has decided to suspend the signing of new treaties and rather focus on industrial policy. Anyway, some FTAs, particularly with the United States, Europe and Korea, have structural deficiencies which have led some critics to consider the need to revise them.

Another element that contributes to the deindustrialization is the appreciation of the Colombian peso, which in recent years has been considerable, especially since 2003. Peso appreciation encourages imports and discourages exports. Revaluation has been so strong that organizations like the National Association of Financial Institutions (ANIF, for its acronym in Spanish), argues that in the Colombian deindustrialization the determinant factor is the behavior of the exchange rate. According to this unionization, in economies such as the Colombia, where the majority of exports are commodities, enclave type, the share of industrial sector in the economy tends to be significantly reduced, i.e., it presents what is known as Dutch Disease. The abundance of foreign exchange from exports of commodities creates a real and persistent currency appreciation, which reduces the competitiveness of other goods and services produced in the country, causes a reduction in industrial and agricultural exports, and therefore significantly stimulates imports, displacing domestic production by foreign production.

From the above it follows that trade openness, FTAs and Colombian peso revaluation, are critical elements in the industrialization of the country. The three processes, inspired by the principle of freedom in international trade, which assumes that all participants are equal to compete in markets is not, as suggested by Stiglitz, genuine free trade but a trade regime directed, in which corporate interests prevail; in other words, it is a negotiation process that is neither democratic nor transparent. 